DEPÓSITO LEGAL ZU2020000153

Esta publicación científica en formato digital

es continuidad de la revista impresa

ISSN 0041-8811

E-ISSN 2665-0428

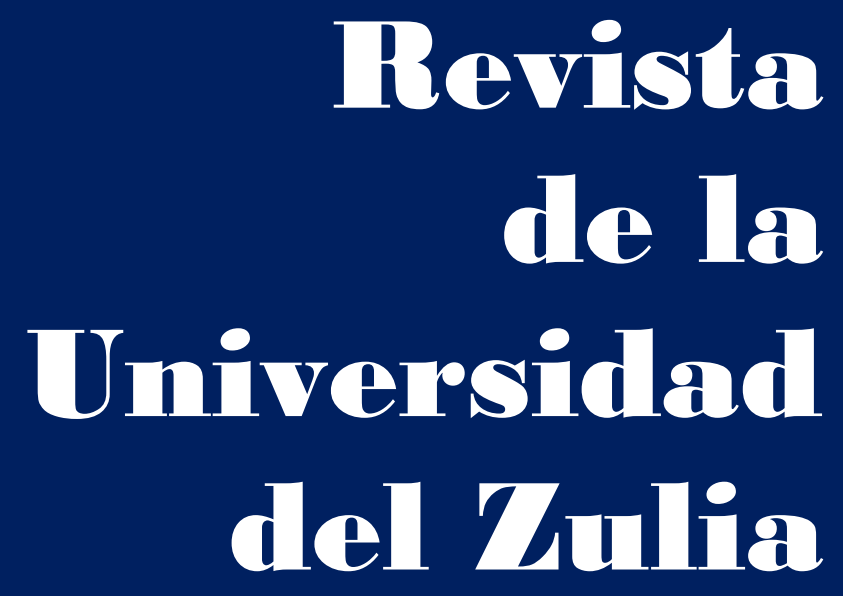

Fundada en 1947

por el Dr. Jesús Emrique Lossada

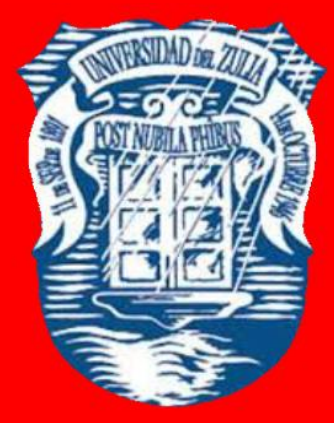

Ciencias

Sociales

y Arte

Año $12 \quad N^{\circ} 34$

Septiembre - Diciembre 2021

Tercera Época

Maracaibo-Veneruela 


\title{
Organizational and legal approaches in fighting organized crime
}

\author{
Viktor A. Baiov* \\ Anton P. Rone ** \\ Raisa V. Perelyhina *** \\ Oleksandr O. Kovtun **** \\ Olesia Y. Urlapova $* * * * *$
}

\begin{abstract}
The purpose of the article is to identify the factors affecting organized crime and to define aspects of tackling it. The methods of statistical analysis, factor analysis, hypotheticaldeductive method, correlation method, generalization method and analogue method were used. The article identified countries with high and low levels of organized crime. Impact of economic development and corruption on the level of organized crime was proved insignificant. Legal factor is not the key aspect of tackling organized crime. Legal approach in tackling organized crime includes: adoption of an international normative legal acts on mutual assistance; development and signing of international agreements on cooperation; development of national and international strategies. The organizational approach implies: international cooperation; decentralization of public oversight authorities and law enforcement agencies in the system of control; development of a program of public involvement; partnership building between state and public institutions.
\end{abstract}

KEY WORDS: crime; crime prevention; international cooperation; legislation.

*Department of Operatively-Search Activities Odessa State University of Internal Affairs, Odesa, Ukraine. ORCID: https:/orcid.org/0000-0001-9005-7382. E-mail: viktorbv8@gmail.com

**Department of Criminal Law and Procedure, Kyiv University of Law of NAS of Ukraine, Kyiv, Ukraine. ORCID: https://orcid.org/0000-0003-4014-7341. E-mail: antonrone@ukr.net

***Department of Criminal Law and Procedure, Kyiv University of Law of NAS of Ukraine, Kyiv, Ukraine. ORCID: https://orcid.org/0000-0002-3798-0861. E-mail: RaisaPerel@ukr.net

****Department of Criminal Law and Procedure, Kyiv University of Law of NAS of Ukraine, Kyiv, Ukraine. ORCID: https://orcid.org/0000-0003-1117-3823. E-mail: kovtuno@ukr.net

*****Department of Criminal Law and Procedure, Kyiv University of Law of NAS of Ukraine, Kyiv, Ukraine. ORCID: https://orcid.org/0000-0002-8370-9247. E-mail: urlapol@ukr.net 


\section{Enfoques organizativos y legales en la lucha contra la delincuencia organizada}

RESUMEN

El propósito del artículo es identificar los factores que afectan al crimen organizado y definir aspectos para enfrentarlo. Se utilizaron los métodos de análisis estadístico, análisis factorial, método hipotético-deductivo, método de correlación, método de generalización y método analógico. El artículo identificó países con altos y bajos niveles de crimen organizado. El impacto del desarrollo económico y la corrupción en el nivel del crimen organizado resultó insignificante. El factor legal no es el aspecto clave para combatir el crimen organizado. El enfoque legal en la lucha contra la delincuencia organizada incluye: adopción de actos jurídicos normativos internacionales sobre asistencia mutua; desarrollo y firma de acuerdos internacionales de cooperación; desarrollo de estrategias nacionales e internacionales. El enfoque organizativo implica: cooperación internacional; descentralización de las autoridades de supervisión pública y los organismos encargados de hacer cumplir la ley en el sistema de control; desarrollo de un programa de participación pública; construcción de asociaciones entre el estado y las instituciones públicas.

PALABRAS CLAVE: crimen; prevención del crimen; cooperación internacional; legislación.

Introduction

Organized crime activity is a global phenomenon that affects people's daily lives. The crimes, committed by an organized gang, are more difficult to solve than other crimes, because organised crime groups successfully conceal them in order to prevent solution of these crimes by law enforcement agencies. It is also more difficult to eradicate organized crime activity, as in some countries the creation of similar organizations is a part of the way of life of the local population and even of the culture as a whole (UNODC, n. d.).

Many criminal organizations and networks operate at the transnational level. Much of the world suffers from some form of organized crime, but it manifests itself differently in various societies (Neumann and Elsenbroich, 2017; Khyzhniak et al, 2021). Harmful effects of modern cross-border criminality are far-reaching, threatening the human security and national security, undermining the global economy, discrediting the supremacy of law and confidence of people in the ability of law enforcement agencies to give them protection (Interpol, 2017). 
REVISTA DE LA UNIVERSIDAD DEL ZULIA. $3^{a}$ época. Año $12 \mathrm{~N}^{\circ}$ 34, 2021

Viktor A. Baiov et al. /// Organizational and legal approaches in fighting organized crime, 297-316

DOI: http://dx.doi.org/10.46925//rdluz.34.18

Defining the structure of organized crime, the psychology and the reasons for the creation of organized crime groups will help to understand their essence, which, in turn, will help to counteract it and develop effective methods of combating organized crime.

The purpose of the scientific article is to identify the factors that affect the level of organized crime and to evidentiate organizational and legal aspects in the fight against organized crime.

Research tasks of the article are the following:

1. To identify the countries with the highest and the lowest levels of organized crime.

2. To identify the factors affecting the level of organized crime.

3. To analyse statistical indicators of the factors influencing the level of organized crime in the specified countries.

4. To investigate the impact of the determined factors on the development of organized crime.

5. To identify organizational and legal approaches in the fight against organized crime.

\section{Literature Review}

Organized crime is the most dangerous and brutal form of association of several people in order to commit a criminal act (Božić, 2016). The comprehension of organized crime is limited to two competing concepts: 1 . A set of sustainable organizations, illegal per se, or members of which systematically participate in crimes. 2. A set of serious criminal actions, which come in the form of illicit trafficking of illegal goods and services, mainly committed for pecuniary advantage by deception (Paoli, 2014).

A criminal organization does not differ fundamentally from a social organization. Depending on the time and context, some actions and forms of an organization are defined as criminal, and then, intentionally or unintentionally, they are considered to be significantly different from the social organization. This assertion is based on the fact that a criminal organization is not significantly different from a social organization, and therefore, in order to understand the emergence of a criminal organization and its basic mechanism, the study of organized crime should begin with the basic principles of social organization (Rostami, 2016). 
Until the 1980-s, organized crime was not considered to be a European problem. However, the term is now widely used in Europe because the prohibition of some popular drugs has created organized crime, working in the illegal drug market. Also due to some problems, related to organized crime, other forms of felonies, such as forgery of coins, armed robberies, arms trafficking, importation of counterfeit goods and counterfeiting have been rethought over the years in terms of the originally American concept (Fijnaut, 2016).

In the 1990-s, the increasing globalization was marred by the growth and diversification of organized crime groups. The range of potential criminal activities is huge, from drugs, weapons and human traffic to more "crafty" but very harmful forms of economic criminality, such as VAT fraud, money laundering, cigarette smuggling, piracy and product counterfeiting. In the mid-1990s, the recognized threat of organized crime (especially of its central role in drug trafficking) led to the creation of European Police Office (Bossong, 2017).

The fight against organized crime in the system of ensuring national security involves implementation at the international, national and departmental (inter-agency) level of a set of legal, organizational (institutional) and practical measures with the purpose of fact-based criminological analysis of this phenomenon, detection and elimination of determinants that contribute to the commission of certain offenses, exposure of persons (organized groups, criminal organizations, gangs and other criminal associations) who commit crimes, cessation of criminal wrongdoings at the stages of preparation or endeavour, as well as prevention (minimization) of their negative consequences, such as compensation for damages, asset recovery, restoration of rights of victims (Vasylevych, 2014).

Two decades of cooperation between the EU and Latin America in the fight against illicit drug production and illicit traffic of narcotic drugs have had only limited effect in terms of reducing production, trafficking, consumption and organized crime related to them, which has not led to a significant improvement in socio-economic conditions - the problem of inequality, literacy rate, low financial capacity - which cause and exacerbate the problem of illicit drug production and trafficking (Selleslaghs, 2017).

The evolution of organized crime, and hence the violence rate, cannot be perceived only by analysing the state approach to fighting organized crime. In order to ensure policies that can reduce violence, the evolution of organized crime should be studied by observing the development of criminal groups (Atuesta and Pérez-Dávila, 2017). 
Fighting organized crime is aimed at preventing the negative impact on social values. This proactive approach should be based on the principle of legality and be carried out on the basis of premeditated procedures. Currently, organized crime is distinguished with diverse typology, which involves not only constant adaptation and diversification of procedures, but also a specific definition, that should accurately reflect the hypothesis, disposition of constituent elements of crime and penalty for each type of crime (Popescu, 2019).

The basis of the fight against organized crime is the harmonization of national legislation with international strategies, laws and regulations, creation of special agencies for combating organized crime, conduct of special investigative activities through the use of the latest techniques and methods. Drug trafficking, arms trafficking, kidnapping and abduction activities, blackmailing offenses, human trafficking, cybercrimes (Cherniavskyi et al, 2021) and corruption are among the most complex forms of organized crime (Božić and Nikač, 2018).

The disadvantages of the fight against organized crime are: the weaknesses of empirical and analytical anti-organized crime policy, which were caused by technical or political constraints of states. These weaknesses were caused by institutional pathologies of the executive branch authorities themselves (Xenakis, 2020).

\section{Materials and Methods of Research}

The study of organizational and legal approaches to combating organized crime was carried out using the method of statistical analysis in order to identify the countries with the highest and lowest levels of organized crime, as well as for comparing data on the level of organized crime and the level of economic development in the studied countries, types of crimes, committed in particular countries, as well as the level of corruption and the level of migration.

Hypothetical-deductive method was used in the selection of factors affecting the level of organized crime and in the process of derivation of legal and organizational approaches in the fight against organized crime.

Thanks to the method of correlation analysis, it became possible to establish the relationship between the index of organized crime for the period of 2011-2017 and GDP per 
REVISTA DE LA UNIVERSIDAD DEL ZULIA. $3^{a}$ época. Año $12 \mathrm{~N}^{\circ}$ 34, 2021

Viktor A. Baiov et al. /// Organizational and legal approaches in fighting organized crime, 297-316

DOI: http://dx.doi.org/10.46925//rdluz.34.18

capita, the index of organized crime for the period of 2011-2017 and the index of corruption, the index of organized crime for 2011-2017 and the level of migration for 2010 and 2015 in such countries as Finland, Norway, Oman, Iceland, El Salvador, Mexico, Honduras.

The methods of factor analysis, generalization and analogy allowed us to identify the factors affecting the level of organized crime.

The study used the most significant scientific works that reflect the development of scientific thought in the sphere of the fight against organized crime from 2003 to 2020. This period of research analysis was chosen as the one that most clearly reflects the state of organized crime in the modern era.

The paper analyses the following indicators:

- Index Organized Crime for 2011-2017 years, stated in World Bank (2018).

- GDP per capita for the period of 2012-2017 (USD), stated in Trading Economics (2020b).

- International migrant stock, total - El Salvador, Finland, Norway, Iceland, Oman, Honduras, Mexico 2010 and 2015 years, stated in World Bank (2020).

- Corruption Index for the period of 2011-2017 years, stated in Trading Economics (2020a).

- The crime rate by types of crime in 2016 and 2017, stated in the World Data Atlas (2019).

\section{Results of the Research}

The index of organized crime is displayed in indicators from 1 to 7 , reflecting the extent to which organized crime (mafia racketeering, extortion) imposes costs on business, where 1 - largely incurs huge costs, 7 - does not require any costs in general. Thus, a higher index of organized crime indicates its lower level in a particular state. In order to identify the factors and the level of impact of the studied indicators on the level of organized crime, we have determined the countries with the highest and the lowest indices of organized crime as of 2017 (Table 1).

Thus, the countries with the highest index of organized crime, and, accordingly, with the lowest level of organized crime in 2017, include: Finland - 6.78, Norway - 6.64, Oman 6.57, Iceland - 6.46. The countries with the lowest index of organized crime, and, 
REVISTA DE LA UNIVERSIDAD DEL ZULIA. $3^{a}$ época. Año $12 \mathrm{~N}^{\circ}$ 34, 2021

Viktor A. Baiov et al. /// Organizational and legal approaches in fighting organized crime, 297-316

DOI: http://dx.doi.org/10.46925//rdluz.34.18

accordingly, with the highest level of organized crime, include: El Salvador - 1.53, Honduras -2.36, Mexico -2.65 .

Table l. Organized Crime, Index

\begin{tabular}{|c|c|c|c|c|c|c|c|}
\hline & 2011 & 2012 & 2013 & 2014 & 2015 & 2016 & 2017 \\
\hline Finland & 6,58 & 6,69 & 6,57 & 6,58 & 6,77 & 6,75 & 6,78 \\
\hline Norway & 6,64 & 6,38 & 6,23 & 6,10 & 6,24 & 6,61 & 6,64 \\
\hline Oman & 6,64 & 6,74 & 6,81 & 6,67 & 6,55 & 6,57 & 6,57 \\
\hline Iceland & 6,77 & 6,51 & 6,39 & 6,52 & 6,63 & 6,55 & 6,46 \\
\hline $\begin{array}{c}\text { El } \\
\text { Salvador }\end{array}$ & 1,92 & 1,82 & 2,46 & 2,69 & 2,36 & 1,89 & 1,53 \\
\hline Honduras & 2,96 & 2,71 & 2,54 & 2,72 & 2,89 & 2,50 & 2,36 \\
\hline Mexico & 2,69 & 2,90 & 2,88 & 2,74 & 2,62 & 2,55 & 2,65 \\
\hline
\end{tabular}

Source: World Bank (2018).

The level of economic development in the studied countries is shown in Table 2. In 2017, the highest GDP per capita was observed in Norway - \$91,549, in Iceland - \$ 51,045.9, in Finland - \$48,086.7, in Oman - \$15,630.5. The lowest level of GDP per capita in 2017 was registered in Honduras - \$2,176.3, in El Salvador - \$3,441.4, in Mexico - \$10,301.36.

Table 2. GDP per capita for the period of 2012-2017 (USD)

\begin{tabular}{|c|c|c|c|c|c|c|}
\hline & 2012 & 2013 & 2014 & 2015 & 2016 & 2017 \\
\hline Finland & 46538.6 & 45906.8 & 45550.5 & 45647.5 & 46750.2 & 48086.7 \\
\hline Norway & 88604.6 & 88444.9 & 89175.5 & 90029.4 & 90196 & 91549 \\
\hline Oman & 17633.1 & 17100.2 & 16425.7 & 16226.7 & 16225.8 & 15630.5 \\
\hline Iceland & 44032.4 & 45421 & 45854 & 47533.7 & 49985.1 & 51045.9 \\
\hline $\begin{array}{c}\text { El } \\
\text { Salvador }\end{array}$ & 3156.7 & 3212.7 & 3252.6 & 3314.7 & 3382.6 & 3441.4 \\
\hline Honduras & 1982 & 2000.8 & 2025.8 & 2067.3 & 2111.1 & 2176.3 \\
\hline Mexico & 9690.9 & 9693.7 & 9839.1 & 10037.2 & 10205.8 & 10301.36 \\
\hline
\end{tabular}

Source: Trading Economics (2020b).

In order to establish the relationship between the level of organized crime and the level of GDP per capita, it is necessary to conduct the correlation analysis of the indicators in Tables 1 and 2. When carrying out the analysis, we used the following formula:

$$
r=\frac{\sum\left(x_{2}-\underline{x}_{1}\right) \cdot\left(x_{2}-\underline{x}_{2}\right)}{\sqrt{\sum \quad\left(x_{1}-\underline{x}_{1}\right)^{2}} \cdot \sqrt{\sum \quad\left(x_{2}-\underline{x}_{2}\right)^{2}}}
$$


where $\mathrm{x}_{1}$ is the index of organized crime and $\mathrm{x}_{2}$ is the level of GDP per capita, $\mathrm{r}$ is the linear correlation coefficient (the $r$-value).

The linear correlation coefficient between the level of organized crime and GDP per capita in the studied countries during 2012 - 2017 was the following: in $2012-0.715$, in 2013 - 0.697, in $2014-0.682$, in $2015-0.603$, in $2016-0.747$, in $2017-0.748$.

Thus, there is a high correlation index, which indicates direct interrelationship between the level of economic development and the level of organized crime during 2012 2017.

Migration as one of the possible factors influencing organized crime in the studied countries is: the largest in 2010 and 2015 in Mexico, and it declines in Oman, Norway, Finland, El Salvador, Iceland and Honduras.

Table 3. International migrant stock, total - El Salvador, Finland, Norway, Iceland, Oman, Honduras, Mexico

\begin{tabular}{|c|c|c|}
\hline & 2010 & 2015 \\
\hline Finland & 248135 & 315881 \\
\hline Norway & 526799 & 741813 \\
\hline Oman & 816221 & 1844978 \\
\hline Iceland & 35091 & 37522 \\
\hline El Salvador & 40324 & 42045 \\
\hline Honduras & 27288 & 28070 \\
\hline Mexico & 969538 & 1193155 \\
\hline
\end{tabular}

Source: World Bank (2020).

The conducted correlation between the index of organized crime and the number of migrants showed the following indicators. The index of linear correlation of migrants in 2010 and the index of organized crime in 2011 were 0.102 , in $2012-0.165$, in 2013 - 0.155, in 2014 0.086. The index of linear correlation of migrants in 2015 and the index of organized crime in 2015 were 0.221 , in $2016-0.260$, in $2017-0.289$.

Thus, the migration factor affected the level of organized crime at a low level during 2010 and 2017.

The level of corruption in the studied countries is reflected in the corruption index for 2011 - 2017, which is shown in Table 4. 
REVISTA DE LA UNIVERSIDAD DEL ZULIA. $3^{a}$ época. Año $12 \mathrm{~N}^{\circ}$ 34, 2021

Viktor A. Baiov et al. /// Organizational and legal approaches in fighting organized crime, 297-316

DOI: http://dx.doi.org/10.46925//rdluz.34.18

The index of linear correlation between the index of organized crime and the corruption index in 2017 was 0.888, in 2016 - 0.891, in 2015 - 0.812, in 2014 - 0.797, in $2013-$ 0.796 , in $2012-0.812$, in $2011-0.846$.

Table 4. Corruption Index 2011 - 2017 years

\begin{tabular}{|c|c|c|c|c|c|c|c|}
\hline & 2011 & 2012 & 2013 & 2014 & 2015 & 2016 & 2017 \\
\hline Finland & 94 & 90 & 89 & 89 & 90 & 89 & 85 \\
\hline Norway & 90 & 85 & 86 & 86 & 87 & 85 & 85 \\
\hline Oman & 48 & 47 & 45 & 45 & 45 & 44 & 52 \\
\hline Iceland & 83 & 82 & 78 & 79 & 79 & 78 & 77 \\
\hline $\begin{array}{c}\text { El } \\
\text { Salvador }\end{array}$ & 34 & 38 & 38 & 39 & 39 & 36 & 35 \\
\hline Honduras & 26 & 28 & 26 & 29 & 31 & 30 & 29 \\
\hline Mexico & 30 & 34 & 34 & 35 & 35 & 30 & 29 \\
\hline
\end{tabular}

Source: Trading Economics (2020a).

Thus, we have determined the interrelation between the level of corruption and the level of organized crime, as the correlation index was not lower than 0.796 during $2011-2017$.

The crime rate in the countries under investigation differs according to the types of crimes shown in Table 5.

Table 5. Crime rate by the type of crime in 2016, 2017

\begin{tabular}{|c|c|c|c|c|c|c|c|}
\hline & $\begin{array}{c}\text { Homicid } \\
\text { e rate }\end{array}$ & $\begin{array}{c}\text { Theft } \\
\text { rate }\end{array}$ & $\begin{array}{c}\text { Theft of } \\
\text { vehicles } \\
\text { rate }\end{array}$ & $\begin{array}{c}\text { Robber } \\
\text { y rate }\end{array}$ & $\begin{array}{c}\text { Kidnappin } \\
\text { g frequency }\end{array}$ & $\begin{array}{c}\text { Assault } \\
\text { rate }\end{array}$ & $\begin{array}{c}\text { Gun } \\
\text { homicide } \\
\text { rate }\end{array}$ \\
\hline Finland & 1.3 & 401.0 & 104.9 & 29.8 & 0.1 & 28.7 & $\begin{array}{c}0.2 \\
(2016)\end{array}$ \\
\hline Norway & 0.5 & - & 76.1 & 14.7 & - & 39.9 & $\begin{array}{c}0,1 \\
(2015)\end{array}$ \\
\hline Oman & 0.3 & 0.0 & 1.8 & 0.7 & 0.2 & 1.4 & - \\
\hline Iceland & 0.9 & 317.0 & 23.2 & 14.7 & - & 30.8 & $\begin{array}{c}0.1 \\
(2016)\end{array}$ \\
\hline El Salvador & 61.7 & - & $\begin{array}{c}34.2 \\
(2015)\end{array}$ & 59.4 & 0.2 & 58.6 & $\begin{array}{c}66.6 \\
(2016)\end{array}$ \\
\hline Honduras & 41.0 & $\begin{array}{c}145,8 \\
(2016)\end{array}$ & $\begin{array}{c}1,1 \\
(2016)\end{array}$ & 120.8 & 0.2 & 21.8 & $\begin{array}{c}43.5 \\
(2016)\end{array}$ \\
\hline Mexico & 25.7 & 65.2 & 108.7 & 196.1 & 1.5 & 44.2 & 16.5 \\
\hline
\end{tabular}

Source: World Data Atlas (2019). 
REVISTA DE LA UNIVERSIDAD DEL ZULIA. $3^{a}$ época. Año $12 \mathrm{~N}^{\circ}$ 34, 2021

Viktor A. Baiov et al. /// Organizational and legal approaches in fighting organized crime, 297-316

DOI: http://dx.doi.org/10.46925//rdluz.34.18

Thus, in the countries with high levels of organized crime, there is high level of the following types of crimes per 100,000 population:

- the homicide rate in El Salvador, which in 2017 was 61.7, in Honduras - 41, in Mexico - 25.7, in other countries under study, this figure did not exceed 1.3.

- the gun homicide rate: the highest rate is in El Salvador - 66.6 in 2016, in Honduras - 43.5 in 2016, in Mexico - 16.5, in Iceland, Finland and Norway, this figure did not exceed 0.2 in 2016 year.

- the robbery rate is the highest in Mexico - 196.1, in Honduras - 120.8, in El Salvador - 59.4, in Finland - 29.8, in Norway and Iceland - 14.7, in Oman - 0.7.

Based on the analysis of the assault rate, which is the highest in El Salvador - 58.6, in Mexico - 44.2, in Norway - 39.9, in Finland - 28.7, in Honduras - 21.8, in Oman - 1.4 and on the analysis of the kidnapping frequency, which is the highest in Mexico - 1.5, in other countries under study, this figure did not exceed 0.2 , we can conclude that such types of crimes in the countries under study are committed regardless of the level of organized crime.

The results of theft rate and theft of vehicles rate are the opposite in the countries with low levels of organized crime: the highest theft rate is in Finland - 401, in Iceland - 317, in Honduras - 145.8 (2016), in Mexico - 65.2 and the highest theft of vehicles rate is in Mexico - 108.7, in Finland - 104.9, in Norway - 76.1, in El Salvador - 34.2 (2015), in Iceland - 23.2, in Oman - 1.8, in Honduras - 1.1 (2016).

The total weight of seized drugs and precursors in 2016 in Finland was $3568 \mathrm{~kg}$, in Norway - $4598 \mathrm{~kg}$, in Oman - $10547 \mathrm{~kg}$, in Iceland - $407.6 \mathrm{~kg}$, in El Salvador - $10427 \mathrm{~kg}$, in Honduras - $8163 \mathrm{~kg}$, in Mexico - $913025 \mathrm{~kg}$ (UNODC, 2017).

Thus, the leaders in narco-trafficking activities are Latin American countries and Oman.

International organizations, responsible for combating organized crime include: United Nations Interregional Crime and Justice Research Institute; the United Nations Asia and Far East Institute for the Prevention of Crime and the Treatment of Offenders; United Nations Office on Drugs and Crime; the Centre for International Crime Prevention; the Financial Action Task Force (FATF); the International Criminal Court and others.

Legal regulation of the fight against organized crime consists of international laws and regulations: The United Nations Convention Against Transnational Organized Crime, the 
REVISTA DE LA UNIVERSIDAD DEL ZULIA. 3época. Año $12 \mathrm{~N}^{\circ}$ 34, 2021

Viktor A. Baiov et al. /// Organizational and legal approaches in fighting organized crime, 297-316

DOI: http://dx.doi.org/10.46925//rdluz.34.18

United Nations Convention Against Illicit Traffic in Narcotic Drugs and Psychotropic Substances, the United Nations Convention Against Corruption, the United Nations Global Plan of Action against Trafficking in Persons and the International Convention on the Suppression of Acts of Nuclear Terrorism.

Legal instruments for combating organized crime in the studied countries are shown in Table 6.

Special laws regulating the fight against organized crime have been passed in El Salvador and Mexico. Penalty for a crime of organizing or participating in an organized crime group is provided in Oman, El Salvador and Mexico. Additional penalties for committing a crime in an organized group and as an aggravating circumstance are provided in Finland and Honduras.

Thus, most legal instruments and the highest penalty are enshrined in the countries with high levels of organized crime, with the exception of Honduras.

\section{Discussion}

Current criminal activities reflect organized crime, which tends to cross regional and international borders. Globalization and increasing mobility opportunities have undoubtedly affected criminality.

In particular, the main factor that has direct impact on the level of organized crime is the level of economic development. We have proved mutual influence of the level of organized crime and the level of the economy, as GDP per capita is low in those countries where the level of organized crime is high. We agree that the general social basis for preventing organized crime and limiting the possibilities of its functioning and increase in crime is overcoming the crisis in the country: in economics, politics, public ideology and psychology, social sphere, law enforcement activities (Hyzymchuk, 2018).

But we cannot agree that migration processes have impact on organized crime (Overseas Security Advisory Council, 2019). A study of the impact of migration on the level of organized crime showed that the number of migrants living in the specified countries in 2010 and 2015 did not affect the level of organized crime in the period of 2011-2017. 
REVISTA DE LA UNIVERSIDAD DEL ZULIA. 3é época. Año $12 \mathrm{~N}^{\circ}$ 34, 2021

Viktor A. Baiov et al. /// Organizational and legal approaches in fighting organized crime, 297-316

DOI: http://dx.doi.org/10.46925//rdluz.34.18

Table 6: Legal instruments for combating organized crime

\begin{tabular}{|c|c|c|c|c|c|c|c|}
\hline & $\begin{array}{l}\overrightarrow{\widetilde{J}} \\
\text { 节 }\end{array}$ & 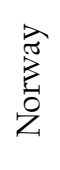 & 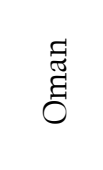 & 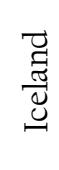 & 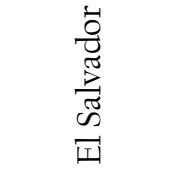 & 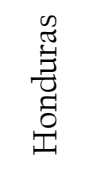 & $\begin{array}{l}\stackrel{0}{\bar{x}} \\
\sum_{\Sigma}^{0}\end{array}$ \\
\hline $\begin{array}{l}\text { Ratification of the } \\
\text { United Nations } \\
\text { Convention Against } \\
\text { Transnational } \\
\text { Organized Crime was } \\
\text { adopted by the } \\
\text { General Assembly in } \\
\text { its resolution } 55 / 25 \text { of } \\
15 \text { November } 2000 \text {. }\end{array}$ & 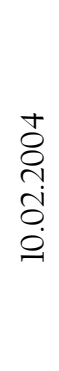 & 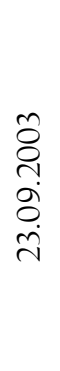 & 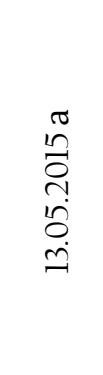 & 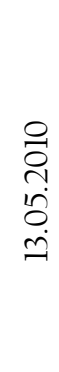 & 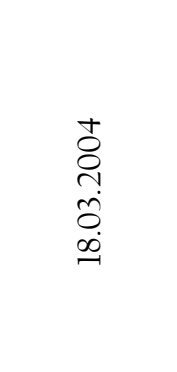 & 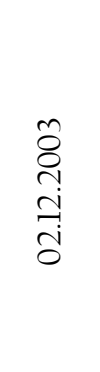 & $\begin{array}{l}\tilde{\delta} \\
\tilde{O} \\
\tilde{n} \\
\dot{0} \\
\dot{0}\end{array}$ \\
\hline $\begin{array}{c}\text { Law on Fight Against } \\
\text { Organized Crime }\end{array}$ & & & ' & & 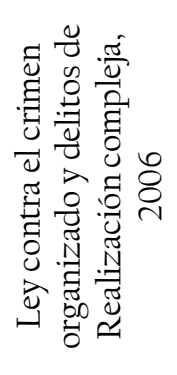 & ' & 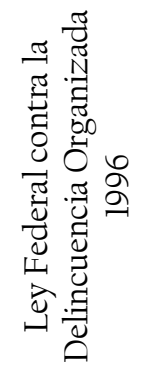 \\
\hline $\begin{array}{l}\text { Defined in the } \\
\text { Criminal Code }\end{array}$ & + & + & 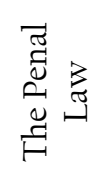 & + & + & 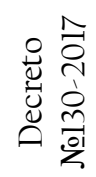 & + \\
\hline
\end{tabular}


REVISTA DE LA UNIVERSIDAD DEL ZULIA. 3é época. Año $12 \mathrm{~N}^{\circ}$ 34, 2021

Viktor A. Baiov et al. /// Organizational and legal approaches in fighting organized crime, 297-316

DOI: http://dx.doi.org/10.46925//rdluz.34.18

\begin{tabular}{|c|c|c|c|c|c|c|c|}
\hline Penalty & 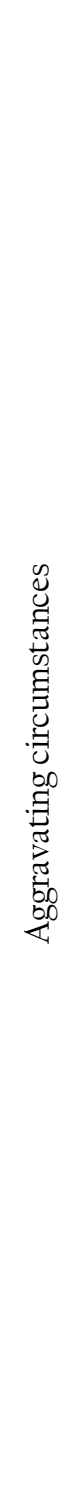 & 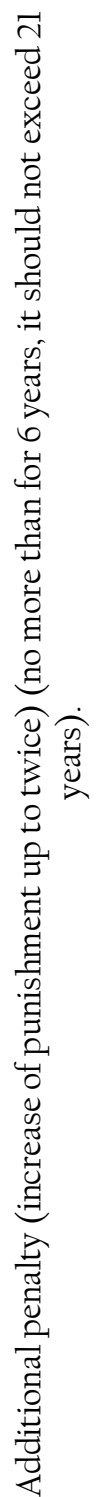 & 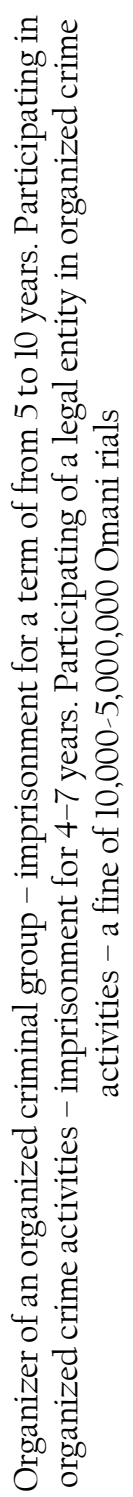 & 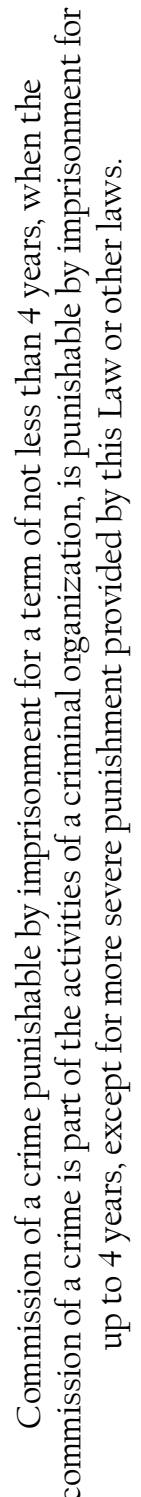 & 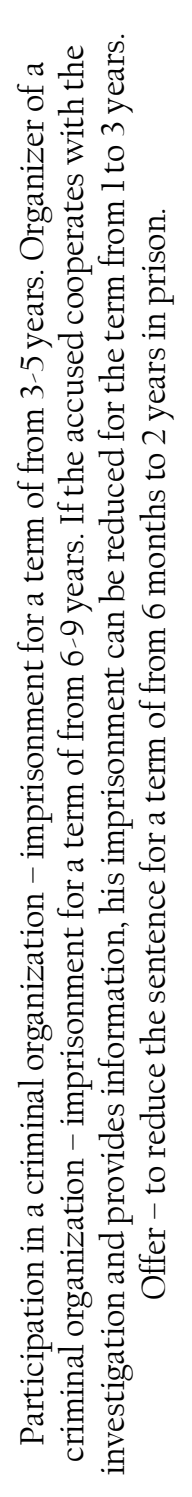 & 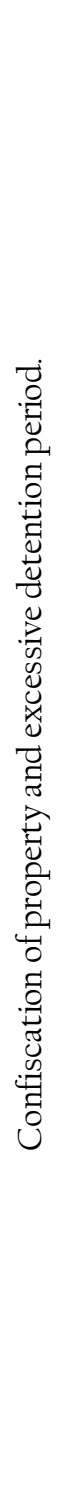 & 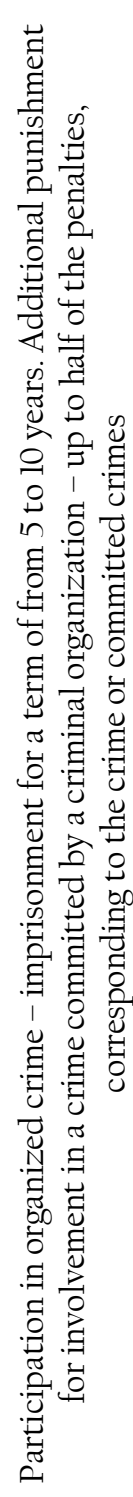 \\
\hline
\end{tabular}


It was found out that the level of organized crime is directly influenced by the level of corruption. This indicates negative cooperation of organized crime groups with law enforcement agencies, as criminal organizations coexist with potentially corrupted law enforcement agencies. Macroeconomic consequences of organized crime and its interaction with corruption are one of the most spectacular examples of poor governance and dysfunctional institutions (Blackburn et al., 2017). Organized crime and corruption appear due to the lack of control from machinery of government and civil society (Buscaglia and van Dijk, 2003). Criminal activity can be so closely intersected with corrupted policies and legitimate business, that they are difficult to separate. Cooperation between countries, international institutions and law enforcement agencies is of utmost importance. Otherwise, proceeds of corruption and organized crime will be hidden abroad or in cyberspace (RoseAckerman and Palifka, 2018).

Recent globalization of information technologies, economics and transportation infrastructure has increased the opportunities and established conditions for the development of organized crime, which is reflected in various types of crimes (par example, drug trafficking, fraud and other deceitful practices); and in the geographical (international, national, local) level of operation (Kirby and Snow, 2016). Organized crime has changed its borders and gone global, which is reflected in the essence of the concept of transnational organized crime (Allum and Gilmour, 2015).

Therefore, the fight against organized crime must be carried out comprehensively at the national and international levels using organizational and legal instruments in compliance with the basic principles: respect for rights and freedoms of persons and legal entities, with the course of law and the supremacy of law, inevitability of responsibility, economic rationale, continuity, innovativeness, priority of advocacy of positive behaviour, prevention of the commission of a crime, scientific validation.

The study found out that legal instruments to combat organized crime are not the key ones. The countries with the highest levels of organized crime (El Salvador, Mexico) have special legislation and severe penalties, but high level of organized crime there remains unchanged. Therefore, legal regulation should be improved in terms of securing the confiscation of property, acquired as a result of committing organized crimes, as organized 
REVISTA DE LA UNIVERSIDAD DEL ZULIA. 3época. Año $12 \mathrm{~N}^{\circ}$ 34, 2021

Viktor A. Baiov et al. /// Organizational and legal approaches in fighting organized crime, 297-316

DOI: http://dx.doi.org/10.46925//rdluz.34.18

crime is a major threat to the economy (Spanò et al., 2016), which directly affects the level of organized crime.

Legal regulation at the international level should consolidate the interaction and cooperation between states. An important component of cooperation between states, as well as unification of criminal legislation at the international level, are treaties and interstate agreements on juridical assistance, which are a kind of legal base for effective cooperation between countries in the fight against organized crime. The provisions of these treaties allow to resolve quickly a range of issues in the field of juridical assistance in criminal cases. It is reasonable to adopt an international regulatory legal act on mutual assistance and cooperation in the fight against organized crime, which will enable to gain comprehension in legal understanding and legal enforcement of criminal laws, as well as it will contribute to the harmonization of national legislations (Vudvud, 2020).

On the basis of this international regulatory legal act, it is necessary to develop a strategy to combat organized crime, which shall be implemented through international collaboration. The creation of global programs of international collaboration in the fight against organized crime reveals recent trends in the activities of organised crime groups and highlights potential dangers, which allows for taking appropriate preventive measures (Nizamedinkhodjaev, 2020).

High level of corruption in the countries with high level of organized crime indicates corrupt practices of public officials and law enforcement agencies. Therefore, it is necessary to create a decentralized system of control over organized crime by both public authorities and law enforcement agencies, as well as to strengthen departmental control and supervision over all law enforcement agencies regardless of the level of their subordination (Kaydashev and Poplavsky, 2020).

In order to combat organized crime effectively, it is necessary to intensify the mechanism of strengthening the state system of disruptive influence on crime and to create social mechanisms that would eliminate system-forming factors that provide for the benefits of organized crime, as well as to overcome the priority of evolution rate of mafia over the evolution rate of government anti-crime and anti-corruption agencies (Dzhuzha, 2018).

Therefore, it is necessary to develop a program of public involvement into the control of organized crime using such information tools, as reporting possible organized crimes; 
reporting about persons who may be organizers or members of a criminal organization; reporting about persons who may have information about organized crime. It would make sense to launch an "information war" (Voronin, 2017) to combat organized crime, which aim s to disclose to the general public criminal goals, plans and work methods of criminal associations, to highlight antisocial and anti-state orientation of crime leaders, to create proper ethical readiness for prevention of the most dangerous forms of organized crime (Vasylevych, 2014).

Effectiveness of the fight against organized crime depends on the strength of the partnership between the prosecutor's office, the police, the tax office, local self-government authorities, enterprises (Groenleer et al., 2020), society, media and international institutions. Mechanisms of international partnership in terms of criminal assistance and cooperation facilitate information swapping, participation in joint investigation teams and other forms of anti-criminal solidarity and partnership (Božić and Nikač, 2018).

In the fight against organized crime, law enforcement agencies should block the development of organized crime, so it is advisable to carry out intelligence surveillance, search and investigative activities using innovative communication technologies (Bell and Congram, 2013), as well as undercover police officers and members of organised crime groups in the fight against organized crime.

\section{Conclusions}

Over the last decade, organized crime has evolved and become increasingly complex. The number of felonies has increased and the boundaries of criminal activity have expanded. We have come to the conclusion, that countries with high levels of organized crime include El Salvador, Honduras and Mexico, all of them belong to Latin American countries. The countries with the lowest levels of organized crime are Finland, Norway, Oman and Iceland.

Countries with high levels of organized crime have high rates of the following types of crimes: homicide, gun homicide, robbery (crimes of violence) and drug-related crimes.

We have identified the mutual influence of the level of economic development on the level of organized crime in all studied countries during 2011-2017. It was also found out, that the level of corruption in the same countries and for the same period 2011-2017 directly affects the level of organized crime. 
The relationship between the level of migration in 2010 and 2015 and the level of organized crime for the period 2011-2017 is very weak.

It has been established in the article that such legal instruments as special legislation and severe penalties for organizing or participating in organized crime are enshrined in the countries with high levels of organized crime, and therefore legal regulation is not a key factor influencing organized crime.

The purpose of crime prevention is to overcome the causes and conditions of crime, and the fight against organized crime includes a number of tools, including legal and organizational ones.

The legal approach to the fight against organized crime includes: adoption of international normative legal acts on mutual assistance and cooperation in the fight against organized crime; development and signing of international treaties and agreements on cooperation in the fight against organized crime; development and adoption of national and international strategies to combat organized crime; legalization of confiscation of property obtained by organized crimes and prevention of legalization of this money.

The organizational approach in the fight against organized crime comprises: international cooperation in the fight against organized crime; decentralization of public oversight authorities and law enforcement agencies in the system of control over organized crime, which will help to prevent corruption; development of a program of public involvement to the control of organized crime with the use of information tools; partnership building between the prosecutor's office, the police, the tax office, local self-government authorities, enterprises, society, media and international institutions, which will create conditions for information swapping; waging an information war against organized crime; carrying out by law enforcement agencies of intelligence surveillance, search and investigative activities using innovative communication technologies, as well as undercover police officers and members of organised crime groups in the fight against organized crime.

\section{References}

Allum, F., Gilmour, S. (Eds.). (2015). The Routledge handbook of transnational organized crime. London, Routledge. 
REVISTA DE LA UNIVERSIDAD DEL ZULIA. $3^{a}$ época. Año $12 \mathrm{~N}^{\circ}$ 34, 2021 Viktor A. Baiov et al. /// Organizational and legal approaches in fighting organized crime, 297-316

DOI: http://dx.doi.org/10.46925//rdluz.34.18

Atuesta, L. H., Pérez-Dávila, Y. S. (2017). Fragmentation and cooperation: The evolution of organized crime in Mexico. Trends in Organized Crime, 21(3), 235-26l. https://doi.org/10.1007/s12117-017-9301-z

Bell, P., Congram, M. (2013). Intelligence-Led Policing (ILP) as a strategic planning resource in the fight against Transnational Organized Crime (TOC). International Journal of Business and Commerce, 2(12), 15-28.

Blackburn, K., Neanidis, K. C., Rana, M. P. (2017). A theory of organized crime, corruption and economic growth. Economic Theory Bulletin, 5, 227-245. https://doi.org/10.1007/s40505-017-0116-5

Bossong, R. (2017). EU-Japan: Fight against terrorism and organized crime. Discussion paper. University of Essex, EU-Japan security cooperation: challenges and opportunities project, online paper series, spring/summer 2017, Colchester, UK. Available at: http://repository.essex.ac.uk/19873/1/EU-

Japan_5_Counterterrorism\%26OC_Bossong_EU.pdf (accessed: 21.04. 2021).

Božić, V. (2016). Suzbijanje organiziranog kriminaliteta u svjetlu pozitivnog kaznenog zakonodavstva Republike Hrvatske [Suppression of organized crime in the light of positive criminal legislation of the Republic of Croatia]. Available at: https://www.bib.irb.hr/950472 (accessed: 21.04.2021).

Božić, V., Nikač, Ž. (2018). Fight against organized crime in the states of the region and EU member states. In: D. Marković (Ed.), Thematic collection of articles - asymmetry and strategy (pp. 339-356). Belgrade, Strategic research institute.

Buscaglia, E., van Dijk, J. (2003). Controlling organized crime and corruption in the public sector. Forum on Crime and Society, 3(1/2), 3-34.

Cherniavskyi, S., Babanina, V., Mykytchyk, O., \& Mostepaniuk, L. (2021). Measures to combat cybercrime: analysis of international and Ukrainian experience. Cuestiones Políticas, 39(69), 115-132. https://doi.org/10.46398/cuestpol.3969.06

Dzhuzha, O. (2018). The experience of foreign countries in the offensive strategy to combat organized crime. Law Magazine of the National Academy of Internal Affairs of Ukraine, $16(2), 13-21$.

Fijnaut, C. (2016). Controlling organized crime and terrorism in the European Union. In: The containment of organised crime and terrorism (pp. 717-733). Leiden, Brill.

Groenleer, M. L. P., Cels, S., De Jong, J. (2020). Safety in the city: building partnerships in the fight against organized crime. In: C. Van Montfort, A. Michels (Eds.), Partnerships for livable cities (pp. 211-228). London, Palgrave MacMillan.

Hyzymchuk, S. S. (2018). Criminological characteristics of organized crime. Molody Vcheny, ll(63), 791-794.

Interpol. (2017). Global strategy on organized and emerging crime. Lyon, Interpol General Secretariat. 
Kaydashev, R. P., Poplavsky, A. A. (2020). Improving the fight against organized crime. Naukovi Perspektivi, 1(1), 50-59.

Khyzhniak, Y., Kapustnyk, V., Batrachenko, T., Chuprikova, I., \& Kryshchenko, A. (2021). International experience in preventing intentional homicide by criminal police units. Cuestiones Politicas, 39(69), 630-642. https://doi.org/10.46398/cuestpol.3969.39

Kirby, S., Snow, N. (2016). Praxis and the disruption of organized crime groups. Trends in Organized Crime, 19(2), 111-124. https://doi.org/10.1007/s12117-016-9269-0

Neumann, M., Elsenbroich, C. (2017). Introduction: the societal dimensions of organized crime. Trends in Organized Crime, 20, 1-15. https://doi.org/10.1007/sl2117-016-9294-z

Nizamedinkhodjaev, U. (2020). The role of international cooperation in the fight against crime. European Journal of Humanities and Social Sciences, 1, 173-179. https://doi.org/10.29013/EJHSS-20-1-173-179

Overseas Security Advisory Council (2019). Norway 2019 crime and safety report. Available at: https:/www.osac.gov/Country/Norway/Content/Detail/Report/la4b3blf-elcl-40a899c9-15f4aeb21243 (accessed 21.04.2021).

Paoli, L. (2014). Organized crime, types of. In: G. Bruinsma, D. Weisburd (Eds.), Encyclopedia of criminology and criminal justice (p. 40). New York, Springer. https://doi.org/10.1007/978-1-4614-5690-2_628

Popescu, T. V. (2019). Fight against crime - criminological perspective. In: I.-G. Rotaru (Ed.), The 13th International RAIS Conference on Social Sciences and Humanities (pp. 213-219). Beltsville, RAIS.

Rose-Ackerman, S., Palifka, B. J. (2018). Corruption, organized crime, and money laundering. International Economic Association series. In: K. Basu, T. Cordella (Eds.), Institutions, governance and the control of corruption vol. 4 (pp. 75-111). Cham, Palgrave Macmillan. https://doi.org//10.1007/978-3-319-65684-7_4

Rostami, A. (2016). Criminal organizing: studies in the sociology of organized crime [Doctoral dissertation]. Stockholm, Stockholm University.

Selleslaghs, J. (2017). The EU's performance in Latin America's fight against drugs and related $\begin{array}{llll}\text { organized crime. } & \text { Global } & \text { Affairs, } & \text { 2(50), }\end{array}$ https://oi.org/10.1080/23340460.2016.1276403

Spanò, R., Paola, N. D., Caldarelli, A., Vona, R. (2016). Accountants' hybridization and juridification: a critical reflection on the fight against organized crime. Public Money and Management, 36(6), 441-446. https://doi.org/10.1080/09540962.2016.1190208

Trading Economics (2020a). Corruption index. Available at: https://tradingeconomics.com/mexico/corruption-index (accessed 21.04.2021).

Trading Economics (2020b). GDP per capita. Available at: https://tradingeconomics.com/mexico/gdp-per-capita (accessed 21.04.2021).

UNODC (2017). Individual drug seizure cases (IDS). Available at: https://dataunodc.un.org/ids (accessed 21.04.2021). 
UNODC. (n .d.). Organized crime. E4J University module series. Available at: https://www.unodc.org/e4j/tertiary/organized-crime.html (accessed 21.04.2021).

Vasylevych, V. V. (2014). Principles of criminological policy of Ukraine. Issues of Crime Prevention, 27, 82-90.

Voronin, S. A. (2017). Specific features of criminal law characteristics of organized crime. Available at: https://www.abacademies.org/articles/specific-features-of-criminal-lawcharacteristics-of-organized-crime-6715.html (accessed 21.04.2021).

Vudvud, K. (2020). Fundamentals of interaction of states in the field of combating transnational organized crime: legal aspects. In: V. Bujor (Ed.), Particularitățile adaptării legislației Republicii Moldova și Ucrainei la legislația Uniunii Europene, 27-28 martie 2020 [Particulars of legislative adaptations of the Republic of Moldova and Ukraine to the legislation of the Union of Europe, March 27-28, 2020] (pp. 150-154). Chişinău, Tipocart Print.

World Bank (2018). Organized crime, index. Available at: https://tcdata360. worldbank.org/indicators/h303lde56? country=BRAandindicator=677andvi $z=$ choroplethandyears=2017andcompareBy=income (accessed 21.04.2021).

World Bank (2020). International migrant stock, total - El Salvador, Finland, Norway, Iceland, Oman, Honduras, Mexico. Available at: https://data.worldbank.org/indicator/SM.POP.TOTL?end=2017andlocations=SV-FI-NO-ISOM-HN-MXandname_desc=falseandstart=1962andview=chart (accessed 21.04.2021).

World Data Atlas (2019). Crime statistics. Available at: https://knoema.com/atlas/Honduras/topics/Crime-Statistics (accessed 21.04.2021).

Xenakis, S. (2020). Incapacity, pathology, or expediency? Revisiting accounts of data and analysis weaknesses underpinning international efforts to combat organised crime. Trends in Organized Crime, 24, 6-22. https://doi.org/10.1007/s12117-020-09387-7 